\title{
Karakteristik Organoleptik dan Sifat Kimia Fruit Leather Nanas (Ananas comosus L. Merr) dengan Penambahan Karagenan dan Gelatin sebagai Gelling Agent
}

\author{
Organoleptic Characteristics and Chemical Properties of Fruit Leather Nanas (Ananas \\ comosus L. Merr) with the Addition of Carrageenan and Gelatin as Gelling Agents
}

\author{
Hamka Nurkaya $^{1^{\star}}$, Amran $^{2}$, Marwati $^{2}$, Khusnul Khotimah $^{1}$, Eva Nurmarini ${ }^{1}$ \\ ${ }^{1} J u r u s a n$ Teknologi Pertanian, Politeknik Pertanian Negeri Samarinda, Indonesia \\ ${ }^{2}$ Fakultas Pertanian Universitas Mulawarman, Samarinda, Indonesia \\ "Corresponding author: hamka@politanisamarinda.ac.id
}

\begin{abstract}
ABSTRAK
Di Kalimantan Timur, buah nanas sangat berlimpah namun masyarakat setempat belum memanfaatkannya sebagai olahan yang berkualitas tinggi padahal buah nanas sangat berpotensi untuk diolah menjadi produk-produk yang memiliki nilai jual tinggi seperti halnya dalam diversifikasi pangan, salah satunya adalah dengan pengolahan fruit leather. Dalam pengolahan fruit leather sering terjadi beberapa kendala, salah satunya adalah plastisitas yang kurang baik. Oleh karena itu untuk memenuhi kriteria tersebut diperlukan penambahan bahan pengikat yang dapat memperbaiki plastisitas dari fruit leather dengan menggunakan bahan karagenan dan gelatin. Penelitian ini menggunakan Rancangan Acak Lengkap (RAL) faktor tunggal dengan lima perlakuan dan tiga kali ulangan. Faktor tunggal dalam penelitian ini adalah perbandingan antara karagenan dan gelatin. Dimana perlakuan adalah P1 (1g:0g), P2 (0,75g:0,25g), P3 (0,50g:0,50g), P4 (0,25g:0,75g), dan P5 (0g:1g) untuk setiap 100 gram bahan. Data yang diperoleh dianalisis menggunakan sidik ragam (ANOVA) dan uji lanjut menggunakan uji beda nyata jujur (BNJ) pada taraf $\alpha 5 \%$. Hasil penelitian ini menunjukkan bahwa pengaruh perbandingan penambahan antara karagenan dan gelatin berpengaruh nyata terhadap organoleptik untuk warna dan rasa, namun berpengaruh tidak nyata terhadap organoleptik untuk aroma dan tekstur serta berpengaruh nyata terhadap kadar air, kadar abu, kadar serat dan vitamin C. Penambahan terbaik berdasarkan tingkat kesukaan terhadap warna, aroma, tekstur dan rasa terdapat pada perbandingan (100:0). Perbandingan ini memiliki kadar air 9,44\%, kadar abu $2,88 \%$, kadar serat $1,98 \%$, dan vitamin C $15,51 \mathrm{mg}$.
\end{abstract}

Kata Kunci: fruit leather, nanas, karagenan, gelatin, uji organoleptik

\section{ABSTRACT}

In East Kalimantan, pineapple fruit is very abundant, but the local community has not utilized it as a high quality product, even though pineapple has the potential to be processed into products that have high selling value as is the case in food diversification, one of which is processing fruit leather. In the processing of fruit leather, several obstacles often occur, one of which is poor plasticity. Therefore, to meet these criteria it is necessary to add a binder that can improve the plasticity of the fruit leather by using carrageenan and gelatin. This study used a single factor completely randomized design (CRD) with five treatments and three replications. The single factor in this study was the comparison between carrageenan and gelatin. Where the treatments are $P 1(1 \mathrm{~g}: 0 \mathrm{~g}), P 2(0.75 \mathrm{~g}: 0.25 \mathrm{~g}), P 3(0.50 \mathrm{~g}: 0.50 \mathrm{~g}), P 4(0.25 \mathrm{~g}: 0.75 \mathrm{~g})$, and P5 (0g: $1 \mathrm{~g})$ for every 100 grams of ingredients. The data obtained were analyzed using analysis of variance (ANOVA) and further tests using the honest real difference test (BNJ) at the a $5 \%$ level. The results of this study indicated that the effect of the addition of carrageenan and gelatin had a significant effect on organoleptics for color and taste, but had no significant effect on organoleptics for aroma and texture. The addition of carrageenan and gelatin also had a significant effect on moisture content, ash content, fiber content and vitamin $C$. The best addition based on the level of preference for color, aroma, texture and taste is in the ratio (100: 0). This ratio has a moisture content of $9.44 \%, 2.88 \%$ ash content, $1.98 \%$ fiber content, and $15.51 \mathrm{mg}$ of vitamin C.

Keywords: fruit leather, pineapple, carrageenan, gelatin, organoleptic test

\section{PENDAHULUAN}

Indonesia merupakan salah satu negara tropis yang memiliki potensi buah dan sayur yang tinggi dalam pemanfaatan dan produktivitasnya. Namun, buah dan sayur masih memiliki tingkat konsumsi yang sangat rendah yaitu 74 kkal sehari untuk buah dan 36 kkal sehari untuk sayur, sehingga terjadi ketidak seimbangan yang menyebabkan kurang pengetahuannya masyarakat tentang 
bagaimana cara pengolahan untuk meningkatkan pola konsumsi pangan terhadap buah dan sayur (BPS, 2014). Buah nanas (Ananas comosus L. Merr) saat ini hanya dikonsumsi dalam bentuk segar dan sejauh ini buah nanas diolah menjadi selai maupun sebagai flavour pada produk lain yang beredar dimasyarakat. Di Kalimantan buah nanas sangat berlimpah namun masyarakat setempat belum memanfaatkan buah nanas sebagai olahan yang berkualitas padahal buah nanas sangat berpotensi untuk diolah menjadi produk-produk yang memiliki nilai jual tinggi seperti halnya dalam diversifikasi pangan, salah satunya adalah dengan pengolahan fruit leather.

Fruit leather merupakan suatu produk olahan buah yang memanfaatkan tehnik pengeringan, yang memiliki tekstur kenyal dan flavorful. Namun menurut Hamzah dan Rahmayuni (2017), fruit leather yang berkualitas memiliki kandungan air $10-20 \%$, nilai $a_{w}$ kurang dari 0.7 , memiliki kenampakan yang tipis namun masih dapat digulung, tekstur yang plastis, dapat dikonsumsi secara langsung serta memiliki warna, aroma dan rasa yang khas dari jenis bahan baku yang digunakan. Kriteria fruit leather ditentukan oleh kandungan serat asam, kandungan gula, dan kandungan serat yang tinggi. Dalam pengolahan fruit leather sering terjadi beberapa kendala, salah satunya adalah plastisitas yang kurang baik. Oleh karena itu untuk memenuhi kriteria tersebut diperlukan penambahan bahan pengikat yang dapat memperbaiki plastisitas fruit leather tersebut. Salah satu bahan yang digunakan adalah karagenan dan gelatin. Karagenan merupakan hasil ekstraksi polisakarida dari beberapa spesies rumput laut atau alga merah (Rhodophyceae) (Distantina, dkk., 2010). karagenan dapat digunakan dalam industri pangan karena memiliki karakteristik yang dapat membentuk jelly, berfungsi sebagai pengental, dan menstabilkan bahan utama dari suatu produk. Selain karagenan, gelatin juga salah satu bahan yang dapat digunakan dalam pembuatan fruit leather. Kegunaan dari gelatin hampir sama dengan karagenan yaitu sebagai pengental dan penstabil keplastisitasan fruit leather. Gelatin merupakan parsial protein serabut kolagen yang terdapat pada tulang, kulit dan jaringan ikat hewan yang di hidrolisis menjadi suatu protein (Puspawati, dkk., 2012). Adapun tujuan penelitian ini adalah untuk mengetahui pengaruh penambahan karagenan dan gelatin sebagai gelling agent terhadap karakteristik organoleptik dan sifat kimia pada pembuatan fruit leather nanas.

\section{METODE PENELITIAN}

\section{A. Alat dan Bahan Penelitian}

Penelitian ini dilaksanakan di Labolatorium Kimia dan Pengolahan Hasil Pertanian, Jurusan Teknologi Hasil Pertanian, Fakultas Pertanian, Universitas Mulawarman, Samarinda Kalimantan Timur. Bahan yang digunakan dalam penelitian ini terdiri dari buah nanas jenis queen yang telah matang yang diperoleh dari pasar lokal, karagenan (berjenis kappa) yang diperoleh dari toko online, gelatin diperoleh ditoko yang bertempat didaerah Lambung Mangkurat, Samarinda yang bermerek halal, gula pasir, dan air. Serta bahan-bahan yang digunakan dalam analisis. Adapun alat yang digunakan adalah blender, kompor, oven, panci, thermometer, sendok, wadah, pisau, timbangan, gelas piala, loyang, aluminium foil dan kertas roti.

\section{B. Prosedur Pembuatan Fruit Leather Buah Nanas}

Tahapan awal yang dilakukan dalam pembuatan fruit leather yaitu buah nanas disortasi, kemudian dikupas kulitnya lalu di potong-potong untuk mempermudah proses pemblenderan. Kemudian buah nanas di blancing selama 8 menit. Selanjutnya bubur buah nanas di timbang sebanyak $100 \mathrm{mg}$ kemudian ditambahkan gelling agent (karagenan dan gelatin) sesuai perlakuan. Dilanjutkan dengan pemanasan pada suhu $50^{\circ} \mathrm{C}$ selama 30 detik. Setelah itu adonan di tuang kedalam Loyang dan didiamkan selama 8-10 menit hingga dingin, kemudian dilakukan pengeringa pada oven pada suhu $80^{\circ} \mathrm{C}$ selama 6-8 jam.

\section{Rancangan Penelitian}

Penelitian ini untuk menentukan perbandingan penambahan karagenan dengan gelatin pada produk fruit leather dan dirancang sebagai penilitian faktor tunggal yang disusun dalam Rancangan Acak Lengkap (RAL) dengan 5 taraf perlakuan dengan masing-masing 3 kali ulangan. Perlakuan yang digunakan yakni 
penambahan karagenan dan gelatin kedalam adonan fruit leather. Adapun perlakuannya sebagai berikut: P1 (1g:0g), P2 $(0,75 \mathrm{~g}: 0,25 \mathrm{~g}), \quad$ P3 $\quad(0,50 \mathrm{~g}: 0,50 \mathrm{~g}), \quad$ P4 $(0,25 \mathrm{~g}: 0,75 \mathrm{~g})$, P5 (0g:1g) untuk setiap 100 gram bahan. Parameter yang diuji yaitu Uji Organoleptik dan Uji Mutu Organoleptik (uji rasa, aroma, warna, dan tekstur) dengan menggunakan pemusatan nilai modus metode Setyaningsih (Setyaningsih, 2010) dan fisikokimia (kadar abu, kadar air, kadar serat, dan kadar vitamin C) menggunakan metode Sudarmadji (Sudarmadji, dkk., 1997).

\section{Analisa Data}

Data yang diperoleh dianalisis menggunakan sidik ragam (ANOVA). Data yang menunjukkan perbedaan nyata pada perlakuan, maka akan dilanjutkan dengan Uji Tukey Test pada taraf $\alpha 5 \%$.

\section{HASIL DAN PEMBAHASAN}

Hasil uji organoleptik dan sifat kimia fruit leather dari perbandingan penambahan karagenan dan gelatin pada pembuatan fruit leather nanas.

Tabel 1. Hasil uji organoleptik warna, aroma, tekstur dan rasa terhadap perbandingan penambahan karagenan dan gelatin pada pembuatan fruit leather nanas

\begin{tabular}{|c|c|c|c|c|c|}
\hline \multirow{2}{*}{$\begin{array}{c}\text { Uji } \\
\text { Organoleptik }\end{array}$} & \multicolumn{5}{|c|}{ Perbandingan Penambahan Karagenan dan Gelatin } \\
\hline & $\begin{array}{c}1 \mathrm{~g}: 0 \mathrm{~g} \\
\text { (modus dan } \\
\text { persentase } \\
\text { modus) }\end{array}$ & $\begin{array}{c}0,75 \mathrm{~g}: 0,25 \mathrm{~g} \\
\text { (modus dan } \\
\text { persentase } \\
\text { modus) }\end{array}$ & $\begin{array}{c}0,50 \mathrm{~g}: 0,50 \mathrm{~g} \\
\text { (modus dan } \\
\text { persentase } \\
\text { modus) }\end{array}$ & $\begin{array}{c}0,25 \mathrm{~g}: 0,75 \mathrm{~g} \\
\text { (modus dan } \\
\text { persentase } \\
\text { modus) }\end{array}$ & $\begin{array}{c}0 \mathrm{~g}: 1 \mathrm{~g} \\
\text { (modus dan } \\
\text { persentase } \\
\text { modus) }\end{array}$ \\
\hline Warna & $4,00(72,00 \%)$ & $4,00(57,33 \%)$ & $4,00(68,00 \%)$ & $4,00(58,67 \%)$ & $4,00(56,00 \%)$ \\
\hline Aroma & $4,00(64,00 \%)$ & $4,00(57,33 \%)$ & $4,00(54,67 \%)$ & $4,00(53,33 \%)$ & $4,00(52,70 \%)$ \\
\hline Tekstur & $4,00(68,00 \%)$ & $4,00(60,00 \%)$ & $4,00(54,67 \%)$ & $4,00(57,33 \%)$ & $4,00(49,33 \%)$ \\
\hline Rasa & $4,00(74,67 \%)$ & $4,00(56,00 \%)$ & $4,00(56,00 \%)$ & $4,00(56,00 \%)$ & $4,00(53,33 \%)$ \\
\hline
\end{tabular}

\section{a. Uji Organoleptik}

1) Uji Organoleptik Warna

Nilai uji organoleptik warna fruit leather dari perbandingan karagenan dan gelatin dapat dilihat pada gambar 1. Berdasarkan hasil dari pemusatan data nilai modus menunjukkan bahwa nilai organoleptik warna fruit leather nanas dengan perbandingan karagenan dan gelatin berkisar antara 3,00 $(56,00 \%)$ (Agak suka) sampai dengan 4,00 $(72,00 \%)$ (Suka). Nilai organoleptik warna tertinggi terdapat pada $\mathrm{P} 1$ yaitu $72,00 \%$ dan nilai organoleptik warna terendah terdapat pada P5 yaitu $56,00 \%$. Hal ini menunjukkan bahwa semakin tinggi penambahan karagenan terhadap fruit leather nanas semakin tinggi pula tingkat kesukaan panelis terhadap karakterisitik warna fruit leather, sebaliknya semakin tinggi penambahan gelatin terhadap fruit leather nanas semakin rendah tingkat kesukaan panelis terhadap warna fruit leather nanas. Menurut Trisnawati dan Nisa, (2015), penambahan karagenan dapat mengurangi kadar air pada suatu produk, karena karagenan yang bersifat menyerap air, sehingga semakin banyak penambahan karagenan pada suatu produk maka semakin banyak kadar yang diserap sehingga warna suatu produk yang dihasilkan semakin buram. Menurut Hamka, dkk., (2020), pada penelitian pembuatan permen jelly dari buah naga dengan penambahan karagenan tidak berpengaruh nyata terutama pada parameter organoleptik warna, hal ini diduga disebabkan oleh karagenan tidak memiliki pigmen warna, karagenan lebih bersifat menyerap air. Sifat karagenan sebelum dilarutkan berwarna putih kecoklatan dan setelah dilarutkan dengan air panas akan segera membentuk gel transparan. 


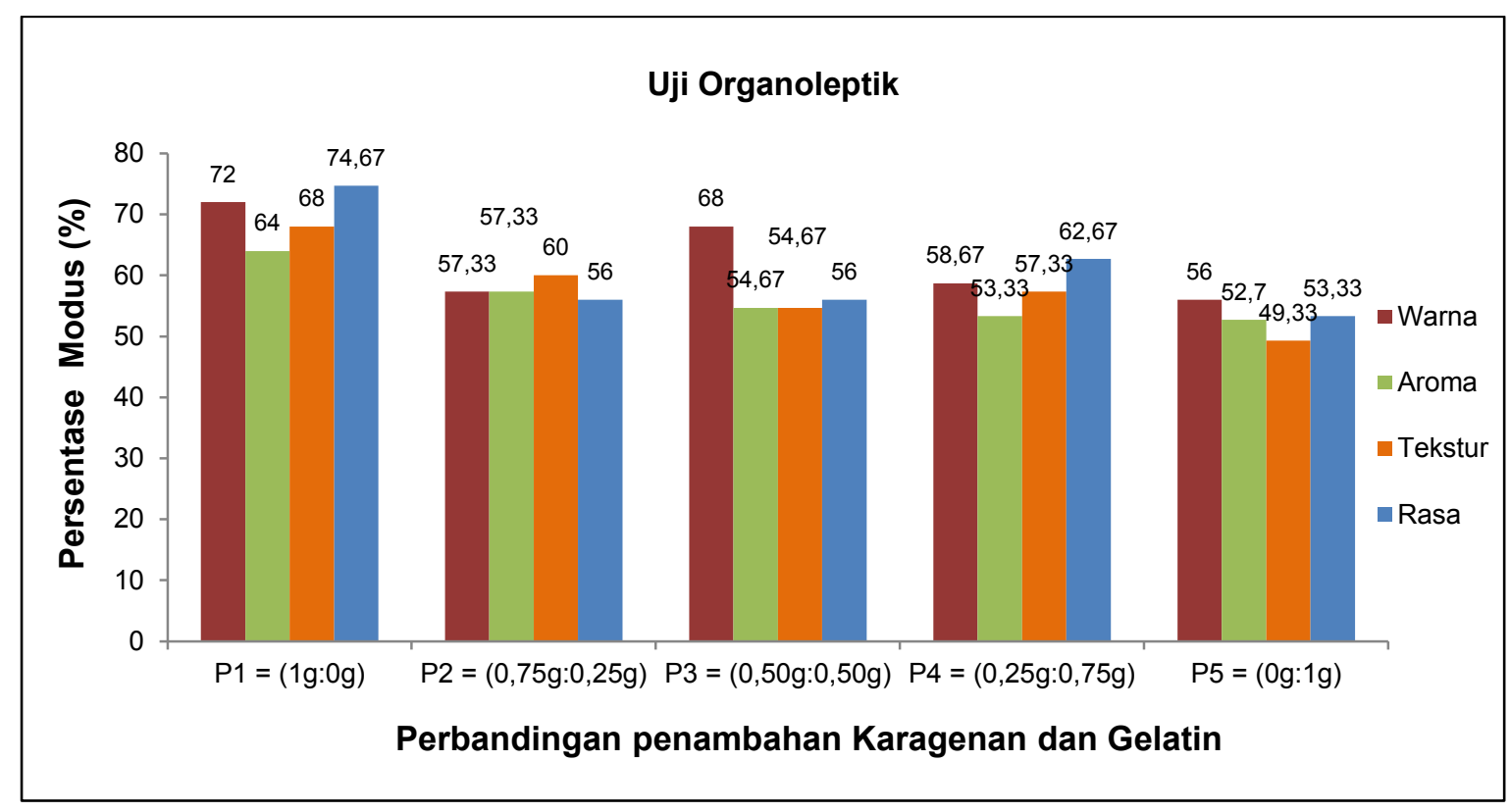

Gambar 1. Nilai Uji Organoleptik Warna, Aroma, Tekstur dan Rasa terhadap perbandingan penambahan Karagenan dan Gelatin pada pembuatan Fruit Leather Nanas

\section{2) Uji Organoleptik Aroma}

Berdasarkan hasil dari pemusatan data nilai modus menunjukkan bahwa nilai organoleptik aroma fruit leather nanas dengan perbandingan karagenan dan gelatin berkisar antara 3,00 (52,70\%) (Agak suka) sampai dengaan $4,00(64,00 \%)$ (Suka). Nilai organoleptik aroma tertinggi terdapat pada P1 yaitu $64,00 \%$ sedangkan nilai organoleptik aroma terendah terdapat pada P5 yaitu $52,70 \%$. Hal ini menunjukkan bahwa semakin tinggi penambahan karagenan maka semakin tinggi pula tingkat kesukaan panelis terhadap aroma fruit leather nanas, sebaliknya semakin tinggi penambahan gelatin, maka semakin rendah tingkat kesukaan panelis terhadap aroma fruit leather nanas. Hal ini disebabkan karagenan yang terbuat dari rumput laut tidak memiliki aroma yang khas dibandingkan dengan gelatin yang terbuat dari kolagen, kulit dan tulang hewan yang memiliki aroma khas, sehingga aroma pada fruit leather dengan penambahan karagenan yang tinggi tidak menghilangkan aroma khas nanas dari fruit leather itu sendiri dibandingkan dengan penambahan gelatin dengan jumlah yang tinggi. Sesuai dengan penelitian Ayudiarti, dkk., (2007), mengatakan bahwa semakin tinggi penambahan gelatin pada suatu produk maka semakin rendah aroma khas dari bahan baku yang digunakan pada produk tersebut.

\section{3) Uji Organoleptik Tekstur}

Berdasarkan hasil dari pemusatan data nilai modus menunjukkan bahwa nilai organoleptik tekstur fruit leather nanas dengan perbandingan karagenan dan gelatin berkisar antara 3,00 (49,33\%) (Agak suka) sampai dengan $4,00(68,00 \%)$ (Suka). Nilai organoleptik tekstur tertinggi terdapat pada P1 yaitu 60,00 , sedangkan nilai organoleptik tekstur terendah terdapat pada P5 yaitu $49,33 \%$. Hal ini menunjukkan bahwa tekstrur pada fruit leather nanas dengan perbandingan karagenan dan gelatin tidak jauh berbeda, karena sifat dari karagenan dan gelatin tidak jauh berbeda, yaitu memiliki kemapuan membentuk jelly. Menurut Zahiruddin, dkk., (2008), karagenan memiliki kemampuan yang dapat mengasilkan tekstur yang baik pada suatu produk. Kemampuan tersebut dapat melakukan interaksi dengan makromolekul yang bermuatan, yang dapat mempengaruhi peningkatan viskositas, pembentukan gel, pengendapan dan stabilisasi.

\section{4) Uji Organoleptik Rasa}

Berdasarkan hasil dari pemusatan data nilai modus menunjukkan bahwa nilai 
organoleptik rasa fruit leather nanas dengan perbandingan karagenan dan gelatin berkisar antara 3,00 (53,33\%) (Agak suka) sampai dengan $4,00 \quad(74,67 \%) \quad$ (Suka). Nilai organoleptik rasa tertinggi terdapat pada $\mathrm{P} 1$ yaitu $74,67 \%$, sedangkan nilai organoleptik rasa terendah pada $P 5$ yaitu $53,33 \%$. Hal ini menunjukkan bahwa semakin tinggi penambahan karagenan pada fruit leather nanas maka semakin tinggi pula tingkat kesukaan panelis dan sebaliknya semakin tinggi penambahan gelatin semakin rendah tingkat kesukaan panelis pada rasa fruit leather nanas. Hal ini diduga karena karagenan yang tidak memiliki rasa yang khas sehingga tidak menghilangkan rasa dari nanas itu sendiri, dibandingkan dengan gelatin yang cenderung memiliki aroma yang khas sehingga berpengaruh terhadap rasa fruit leather.

\section{b. Sifat Kimia}

Tabel 2. Hasil uji sifat kimia terhadap perbandingan penambahan Karagenan dan Gelatin pada pembuatan Fruit Leather Nanas

\begin{tabular}{cccccc}
\hline Sifat Kimia & \multicolumn{5}{c}{ Perbandingan Penambahan Karagenan dan Gelatin } \\
\cline { 2 - 6 } & $1 \mathrm{~g}: 0 \mathrm{~g}$ & $0,75 \mathrm{~g}: 0,25 \mathrm{~g}$ & $0,50 \mathrm{~g}: 0,50 \mathrm{~g}$ & $0,25 \mathrm{~g}: 0,75 \mathrm{~g}$ & $0 \mathrm{~g}: 1 \mathrm{~g}$ \\
\hline K. Air(\%) & $9,44 \pm 0,26^{\mathrm{e}}$ & $10,14 \pm 0,04^{\mathrm{d}}$ & $12,07 \pm 0,05^{\mathrm{c}}$ & $13,26 \pm 0,22^{\mathrm{b}}$ & $14,58 \pm 0,34^{\mathrm{a}}$ \\
K. Abu(\%) & $2,88 \pm 0,00^{\mathrm{b}}$ & $2,41 \pm 0,01^{\mathrm{c}}$ & $2,89 \pm 0,01^{\mathrm{a}}$ & $1,45 \pm 0,00^{\mathrm{d}}$ & $0,96 \pm 0,00^{\mathrm{e}}$ \\
K. serat(\%) & $1,98 \pm 0,00^{\mathrm{a}}$ & $1,48 \pm 0,00^{\mathrm{ab}}$ & $0,98 \pm 0,00^{\mathrm{ab}}$ & $0,65 \pm 0,27^{\mathrm{ab}}$ & $0,48 \pm 0,00^{\mathrm{b}}$ \\
K. Vit C(mg) & $15,51 \pm 0,50^{\mathrm{a}}$ & $14,35 \pm 0,49^{\mathrm{a}}$ & $12,00 \pm 0,49^{\mathrm{b}}$ & $10,83 \pm 0,50^{\mathrm{b}}$ & $09,07 \pm 0,52^{\mathrm{c}}$
\end{tabular}

Keterangan :Data uji kimia pada baris yang sama diikuti oleh huruf yang sama menunjukkan berbeda tidak nyata (Tukey test a $5 \%$ )

\section{1) Kadar Air}

Berdasarkan hasil sidik ragam menunjukkan bahwa perbandingan karagenan dan gelatin berpengaruh nyata terhadap Kadar Air fruit leather nanas yang dihasilkan. Hasil uji lanjut BNJ (Tukey Test) dengan taraf a $5 \%$ menunjukkan bahwa P1 berbeda nyata dengan P2, P3, P4 dan P5. Pada $\mathrm{P} 2$ berbeda nyata dengan $\mathrm{P} 1, \mathrm{P} 3, \mathrm{P} 4$ dan P5. Pada P3 berbeda nyata dengan P1, P2, P4 dan P5. Pad P4 berbeda nyata dengan P1, P2, P3 dan P5. Pada P5 berbeda nyata dengan $\mathrm{P} 1, \mathrm{P} 2, \mathrm{P} 3$ dan $\mathrm{P} 5$. Kadar air fruit leather nanas dari perbandingan karagenan dan gelatin berkisar antara 9,44\% sampai dengan $14,58 \%$. Pada gambar 2 , kadar air tertinggi terdapat pada P5 yaitu $14,58 \%$, sedangkan Kadar air terendah terdapat pada P1 yaitu 9,44. Berdasarkan hasil uji lanjut BNJ (Tukey Test) taraf a 5\% menunjukkan bahwa pengaruh perbandingan karagenan dan gelatin berpengaruh nyata terhadap kadar air. Kadar air tertinggi terdapat pada P5 yaitu 14,58 $\pm 0,34$ (\%), sedangkan kadar air terendah terdapat pada P1 yaitu 9,44 $\pm 0,26(\%)$. Pada uji kadar air fruit leather nanas dengan penambahan karagenan diperoleh kadar air terendah dibandingkan dengan penambahan gelatin. Hal ini disebabkan karena karagenan yang kemampuan menyerap airnya lebih tinggi dibandingkan dengan gelatin. Menurut Trisnawati \& Nisa, (2015) serat pangan yang tinggi yang terdapat pada karagenan dapat memerangkap dalam matriks setelah pembentukan gel dan mengikat air. Faktor lain yang mempengaruhi adalah pada saat pengovenan fruit leather akan mengalami pembentukan film sehingga molekul-molekul air terperangkap dan membentuk gel. Sedangkan pada gelatin berpengaruh tidak nyata pada kadar air fruit leather nanas hal itu karena gelatin yang hanya sebagai gelling egent. Gelatin juga memliki kemampuan yang dapat mengikat air, namun dapat dilihat bahwa kadar air pada fruit leather yang ditambahkan gelatin dengan konsentrasi yang tinggi cenderung meningkat. Menurut Ayudiarti, dkk., (2007), pemanfaatan gelatin pada industri pangan adalah sebagai pembentuk gel yang mampu mengikat air dalam jumlah yang besar. 




Gambar 2. Nilai kadar air dan vitamin C terhadap perbandingan penambahan karagenan dan gelatin pada pembuatan fruit leather nanas

\section{2) Kadar Vitamin C}

Kadar vitamin $\mathrm{C}$ fruit leather nanas dari perbandingan karagenan dan gelatin dapat dilihat pada Gambar 2. Berdasarkan hasil sidik ragam menunjukkan bahwa perbandingan karagenan dan gelatin berpengaruh nyata terhadap Kadar Vitamin C fruit leather nanas yang dihasilkan. Hasil uji lanjut BNJ (Tukey Test) dengan taraf a 5\% menunjukkan bahwa P1 berbeda tidak nyata dengan $P 2$, namun berbeda nyata dengan P3, P4 dan P5. Pada P3 tidak berbeda nyata dengan P4, namun berbeda nyata dengan $\mathrm{P} 1, \mathrm{P} 2$ dan P5. Pada P5 berbeda nyata dengan P1, P2, P3 dan P5. Kadar vitamin C fruit leather nanas dari perbandingan karagenan dan gelatin berkisar antara $9,07 \mathrm{mg} / 100 \mathrm{gr}$ sampai dengan $15,51 \mathrm{mg} / 100 \mathrm{gr}$. Kadar vitamin C tertinggi terdapat pada P1 yaitu $15,51 \mathrm{mg} / 100 \mathrm{gr}$ sedangkan Kadar vitamin $\mathrm{C}$ terendah terdapat pada P5 yaitu $09,07 \mathrm{mg} / 100 \mathrm{gr}$. Berdasarkan hasil uji lanjut BNJ (Tukey Test) taraf a $5 \%$ menunjukkan bahwa pengaruh perbandingan karagenan dan gelatin berpengaruh nyata terhadap kadar vitamin $\mathrm{C}$. Kadar air pada fruit leather nanas dengan perbandingan penambahan antara karagenan dan gelatin berkisar antara 09,07mg/100gr-15,51mg/100gr. Kadar vitamin $\mathrm{C}$ tertinggi terdapat pada $\mathrm{P} 1$ yaitu $15,51 \pm 0,50 \mathrm{mg} / 100 \mathrm{gr}$, sedangkan kadar vitamin $\mathrm{C}$ terendah terdapat pada P5 yaitu $09,07 \pm 0,52 \mathrm{mg} / 100 \mathrm{gr}$. Pada pengujian kadar vitamin $\mathrm{C}$ berpengaruh nyata terhadap fruit leather nanas, hal ini diduga kandungan vitamin $C$ yang terdapat pada buah nanas sangat tinggi ditambah lagi kandungan vitamin $\mathrm{C}$ yang terkandung dalam karagenan itu sendiri. Hal ini membuktikan bahwa semakin tinggi konsentrasi karagenan yang ditambahkan maka semakin tinggi pula kandungan vitamin $\mathrm{C}$ yang terdapat pada fruit leathwer nanas. Hal ini sesuai dengan penelitian Agustin, dkk., (2014), yang mengatakan konsentrasi karagenan yang tinggi mampu membentuk disperse koloid (struktur double helix) lebih banyak dan kuat sehingga akan menghambat oksidasi vitamin C dan akan lebih dapat mempertahankan vitamin C. Dengan struktur double helix yang tinggi maka karagenan lebih kuat melindungi vitamin C dengan matriksnya yang kuat. Sedangkan penambahan gelatin pada fruit leather nanas terhadap kadar vitamin C tidak berpengaruh nyata. Hal ini disebabkan oleh gelatin yang sifatnya tidak terlalu kuat mepertahankan vitamin C. Seperti yang dikatakan oleh Farikha, dkk., (2013), penambahan gelatin akan menyebabkan adanya penarikan partikel-partikel koloid yang lebih banyak pada sari buah. Dengan adanya penarikan partikrl-partikel koloid ini maka lebih sedikit oksigen yang terbebas yang menyebabkan reaksi oksidasi terhadap sari buah. Faktor lain yang diduga menyebabkan turunnya kadar vitamin C 
adalah suhu yang terlalu tinggi pada saat pengovenan.

\section{3) Kadar Abu}

Kadar abu fruit leather nanas dari perbandingan karagenan dan gelatin dapat dilihat pada Gambar 3. Berdasarkan hasil sidik ragam menunjukkan bahwa perbandingan karagenan dan gelatin berpengaruh nyata terhadap Kadar Abu fruit leather nanas yang dihasilkan. Hasil uji lanjut BNJ (Tukey Test) dengan taraf a $5 \%$ menunjukkan bahwa $\mathrm{P} 1$ berbeda nyata dengan P2, P3, P4 dan P5. Pada P2 berbeda nyata dengan $\mathrm{P} 1, \mathrm{P} 3, \mathrm{P} 4$ dan P5. Pada P3 berbeda nyata dengan $\mathrm{P} 1, \mathrm{P} 2, \mathrm{P} 4$ dan $\mathrm{P} 5$. Pad P4 berbeda nyata dengan P1, P2, P3 dan P5. Pada P5 berbeda nyata dengan P1, P2, P3 dan P5. Berdasarkan hasil uji lanjut BNJ (Tukey Test) taraf a $5 \%$ menunjukkan bahwa pengaruh perbandingan karagenan dan gelatin berpengaruh nyata terhadap kadar abu. Kadar abu pada fruit leather nanas dengan perbandingan penambahan antara karagenan dan gelatin berkisar antara 0,96-2,89\%. Kadar abu tertinggi terdapat pada P3 yaitu $2,89 \pm 0,01 \%$ sedangkan kadar abu terendah terdapat pada P5 yaitu $0,96 \%$. Pada uji kadar abu fruit leather nanas menunjukkan perbedaan yang signifikan antar perlakuan. Hal ini diduga semakin tinggi penambahan karagenan maka semakin tinggi pula kadar abu yang terdapat pada fruit leather nanas. Hal ini sesuai dengan penelitian Mahardika, dkk., (2014), yaitu semakin tinggi penambahan gelling agent karagenan pada suatu produk maka meningkat pula kadar abu yang dihasilkan. Kandungan mineral pada suatu bahan berkaitan dengan kadar abu. Seperti yang dikatakan Hastuti dan Sumpe (2007), kandungan mineral yang terdapat pada gelatin adalah $2-4 \%$, kemudian kadar mineral dan kadar abu yang terdapat pada gelatin dapat menurun ketika terjadi pertukaran ion. Pada konsentrasi penambahan gelatin $100 \%$ diperoleh kadar abu terendah, hal ini diduga karena adanya pertukaran ion yang terjadi pada gelatin sehingga menurunnya kadar abu dan mineral pada fruit leather nanas.



Gambar 3. Nilai kadar abu dan kadar serat terhadap perbandingan penambahan Karagenan dan Gelatin pada pembuatan fruit leather nanas

\section{4) Kadar Serat}

Kadar serat fruit leather nanas dari perbandingan karagenan dan gelatin dapat dilihat pada Gambar 3. Hasil sidik ragam menunjukkan bahwa perbandingan karagenan dan gelatin berpengaruh nyata terhadap kadar serat fruit leather nanas yang dihasilkan. Hasil uji lanjut BNJ (Tukey Test) dengan taraf a $5 \%$ menunjukkan bahwa P1 berbeda nyata dengan $P 5$, namun tidak berbeda nyata dengan $\mathrm{P} 2, \mathrm{P} 3$ dan $\mathrm{P} 4$. Pada P2, P3 dan P4 berbeda tidak nyata dengan 
P1 dan P5. Pada P5 berbeda nyata dengan $\mathrm{P} 1$, namun berbeda tidak nyata dengan $\mathrm{P} 2$, P3 dan P4. Kadar serat fruit leather nanas dari perbandingan karagenan dan gelatin berkisar antara 0,48\% sampai dengan $1,98 \%$. Kadar serat tertinggi terdapat pada P1 yaitu 1,98\% sedangkan Kadar serat terendah terdapat pada $\mathrm{P} 5$ yaitu $0,48 \%$. Hasil uji lanjut BNJ (Tukey Test) taraf a 5\% menunjukkan bahwa pengaruh perbandingan karagenan dan gelatin berpengaruh nyata terhadap kadar serat. Kadar air pada fruit leather nanas dengan perbandingan penambahan antara karagenan dan gelatin berkisar antara 0,48-1,98\%. Kadar serat tertinggi terdapat pada P1 yaitu $1,98 \pm 0,00 \%$, sedangkan kadar serat terendah terdapat pada P5 yaitu 0,48 $\pm 0,00 \%$. Pengujian kadar serat pada fruit leather nanas berpengaruh nyata terhadap perbandingan penambahan antara karagenan dan gelatin. Dapat dilihat pada gambar 3, bahwa semakin tinggi konsentrasi karagenan yang ditambahkan maka semakin tinggi pula kadar serat yang dihasilkan. Hal ini sesuai dengan penelitian Asben (2007), mengatakan bahwa semakin tinggi subtitusi rumput laut maka kandungan serat yang terdapat pada fruit leather nanas akan semakin tinggi.

\section{KESIMPULAN}

Berdasarkan hasil penelitian diperoleh kesimpulan bahwa pengaruh perbandingan karagenan dan gelatin pada fruit leather nanas berpengaruh nyata terhadap kadar air, kadar abu, kadar serat kasar dan vitamin $\mathrm{C}$. Perlakuan perbandingan karagenan dan gelatin yang terbaik pada fruit leather nanas yaitu perbandingan karagenan $1 \mathrm{~g}$ dan gelatin og berdasarkan karakteristik kimia. Dari perbandingan ini memiliki kadar air 9,44\%, kadar abu 2,88\%, kadar serat $1,98 \%$ dan vitamin C 15,51 mg. Perlakuan perbandingan karagenan yang lebih besar daripada gelatin cenderung disukai panelis dengan tingkat kesukaan panelis terhadap nilai organoleptik warna, aroma, tekstrur dan rasa (Suka).

\section{DAFTAR PUSTAKA}

Agustin, F., Dwi, W., dan Putri, R. 2014. Pembuatan Jelly Drink Averrhoa blimb L. (Kajian Proporsi Belimbing Wuluh : Air dan Konsentrasi Karagenan). Jurnal Pangan Dan Agroindustri, 2(3), 1-9.

Amertaningtyas, D., Thohari, I., Radiati, L. E., dan Rosyidi, D. 2014. Pengaruh konsentrasi larutan kapur sebagai curing terhadap kualitas fisiko-kimia dan organoleptik gelatin kulit kambing Peranakan Ettawah ( PE ). Jurnal IImuIImu Peternakan, 24(2), 1-7.

Asben, A. 2007. Peningkatan Kadar lodium dan Serat Pangan dalam Pembuatan Fruit Leather Nanas (Ananas comosus L. Merr) dengan Penambahan Rumput Laut.

Ayudiarti, D. L., Suryanti, Tazwir, dan Rosmawaty Paranginangin. 2007. Pengaruh Konsentrasi Gelatin Ikan Sebagai Bahan Pengikat Terhadap Kualitas dan Penerimaan Sirup. Jurnal Perikanan Dan Kelautan, 9(1), 134-141.

BPS. (2014). Ketersediaan Kalori per Kapita Menurut Kelompok Bahan Makanan. Retrieved February 12, 2020, from https://www.bps.go.id/site/resultTab

Distantina, S., Fadilah, Rochmadi, Fahrurrozi, M., dan Wiratni. 2010. Proses Ekstraksi Karagenan dari Eucheuma cottonii. Yogyakarta.

F, S. P. N., Hamzah, F., dan Rahmayuni. (2017). Pemanfaatan Bubur Buah Jambu Biji Putih dan Bubur Buah Pepaya dalam Pembuatan Fruit Leather. Jom Faperta, 4(2), 1-6.

Farikha, I. N., Anam, C., dan Esti Widowati. (2013). Pengaruh Jenis dan Konsentrasi Bahan Penstabil Alami Terhadap Karakteristik Fisikokimia Sari Buah Naga Merah (Hylocereus polyrhizus) Selama Penyimpanan. Jurnal Teknosains Pangan, 2(1).

Hamka, Nurita, Marwati, dan Eva Nurmarini (2020). Pengaruh Sifat Kimia dan Organoleptik Permen Jelly Buah Naga (Hylocereus polyrhizus) dengan Penambahan Karagenan Sebagai Gelling Agent. Buletin Loupe Vol. 16 (1), 8-13.

Hastuti, D., dan Sumpe, I. 2007. Pengenalan dan Proses Pembuatan Gelatin. Peternakan Dan IImu Kelautan, 67(6), 14-21.

Mahardika, B. C., Darmanto, Y., dan Eko Nurcahya Dewi. 2014. Karakteristik Permen Jelly Dengan Penggunaan Semi Refined Carrageenan dan Alginat 
Dengan Konsentrasi Berbeda. Jurnal Pengolahan Dan Bioteknologi Hasil Perikanan, 3(3), 112-120.

Puspawati, N. M., Simpen, I. N., dan Miwada, I. N. S. 2012. Isolasi Gelatin dari Kulit Kaki Ayam Broiler dan Karakteristik Gugus Fungsinya dengan Spektofotometri Ftir. Jurnal Kimia, 6(1), 79-87.

Setyaningsih, D., A. Apriyantono, dan M. P. Sari. 2010. Analisis Sensori untuk Industri Pangan dan Agro.Institut Pertanian Bogor Press. Bogor

Sudarmadji, S., B. Haryono., dan Suhardi. 1997. Prosedur Analisis Untuk Bahan Makanan dan Pertanian. Liberty: Yogyakarta.

Trisnawati, M. I., dan Nisa, F. C. (2015). Pengaruh Penambahan Konsentrat Protein Daun Kelor dan Karagenan Terhadap Kualitas Mie Kering Tersubtitusi Mocaf. Jurnal Pangan Dan Agroindustri, 3(1), 237-247.

Zahiruddin, W., Erungan, A. C., dan Ira Wiraswanti. (2008). Pemanfaatan Karagenan dan Kitosan Dalam Pembuatan Bakso Ikan Kurisi ( Nemipeterus nematophorus) Pada Penyimpanan Suhu Dingin dan Beku. Teknologi Hasil Perikanan, XI(2006), 40-52. 